\title{
Uniformity in the basal metabolic rate of marsupials: its causes and consequences
}

\author{
Uniformidad en la tasa metabólica basal de marsupiales: sus causas y consecuencias
}

\author{
BRIAN K. MCNAB
}

Department of Zoology, University of Florida, Gainesville, Florida 32611, USA; e-mail: bkm@zoo.ufl.edu

\begin{abstract}
Most of the variation (98.8\%) in basal rate of metabolism (BMR) in 70 species of marsupials is correlated with body mass, although lowland species have higher basal rates than highland species and burrowers have lower basal rates than non-burrowers. These factors collectively account for $99.2 \%$ of the variation in marsupial BMR. Marsupials differ in BMR from eutherians by having no species with a high basal rate by general mammalian standards, even when consuming vertebrates or grass, food habits that are associated with very high basal rates in eutherians. The absence of high basal rates in marsupials reflects the absence of a correlation of rate of reproduction with basal rate, a correlation present in eutherians. These differences have two consequences: (1) marsupials are less tolerant of cold environments than eutherians, and (2) marsupials coexist with eutherians only when both have food habits associated with low basal rates and therefore when eutherians have reduced rates of reproduction. In Australia and South America marsupial carnivores diversified in the absence of eutherian equivalents. The importation to mainland Australia of dingos by humans appears to have been the immediate cause for the extinction of thylacines, Tasmanian devils, and eastern quolls. Carnivorous marsupials in South America were replaced by eutherians with the completion of the Panamanian land bridge. Macropods, which have lower basal rates than eutherian grazers, survive in central Australia probably because of their adjustment to xeric environments, whereas introduced domestic stock require the provision of water by humans.
\end{abstract}

Key words: coexistence, competitive exclusion, eutherians, marsupials, reproduction.

\section{RESUMEN}

Gran parte de la variación $(98,5 \%)$ en la tasa metabólica basal de 70 especies de marsupiales se correlaciona con la masa corporal, aunque las especies de tierras bajas tienen tasas basales mayores que las de tierras altas, y las especies subterráneas tienes BMR's menores que las no subterráneas. Colectivamente, estos factores dan cuenta de un 99,2\% en la variación de la BMR de los marsupiales. Los marsupiales difieren de los euterios por no tener especies con altas BMR's, esto según los estándares generales para mamíferos. Esto ocurre, incluso a pesar de consumir vertebrados o pastos, estos últimos, hábitos tróficos asociados con altas BMR en mamíferos euterios. La ausencia de altas tasas basales en marsupiales refleja la ausencia de correlación entre la tasa de producción con BMR, una correlación que sí está presente en euterios. Estas diferencias tienen dos consecuencias: (1) los marsupiales son menos tolerantes a ambientes fríos que los euterios, y (2) los marsupiales coexisten con los euterios solo cuando sus hábitos alimentarios están asociados a BMR's bajos y además cuando los euterios poseen tasas de reproducción bajas. En Australia y Sudamérica los marsupiales carnívoros se diversificaron en ausencia de euterios equivalentes. La importación de los dingos Australianos por los humanos, parece ser la causa inmediata de la extinción de los tilacinos y del demonio de Tasmania. Cuando se terminó de formar el puente de Panamá los carnívoros de Sudamérica fueron reemplazados por euterios. Los macrópodos, que poseen BMRs más bajas que los pastoreadores euterios, sobreviven en Australia central pues probablemente son capaces de tolerar ambientes xéricos, mientras que los herbívoros domésticos requieres de la provisión humana de agua.

Palabras clave: coexistencia, exclusión competitiva, euterios, marsupiales, reproducción. 


\section{INTRODUCTION $^{1}$}

The basal rate of metabolism (BMR) is a standard measure of energy expenditure in endotherms. It is defined as the minimal rate of metabolism measured in the zone of thermoneutrality, when an endotherm is thermoregulating, post-absorptive, and inactive during the period of inactivity (McNab 1997). BMR gives a standard by which to compare the energetics of different endotherms, which often live in different climates, have different behaviors, eat different foods, and are characterized by different morphologies. That is, differences in standard rate of metabolism reflect differences in the animals studied, not differences in the measurements made or in the conditions to which the animals were exposed. Furthermore, many aspects of the life history of endotherms correlate with BMR independent of body size, including maximal rate of metabolism (Bozinovic 1992, but see Koteja 1987), field energy expenditure (Nagy 1994, Speakman 2000), and reproductive rate (McNab 1980). The study of BMR has given insight into some aspects of the comparative biology of endotherms that could not easily have been obtained by other methods.

Many factors have been suggested to influence BMR, most importantly body size, as measured by body mass. As with most sizedependent biological phenomena, BMR is described as a power function of body mass. Mass then accounted for $95.6 \%$ of the variation in total BMR, and $77.7 \%$ of massspecific BMR, in a survey of 320 species of mammals (McNab 1988a). In this case, the fitted power of body mass was 0.713 . The power of body mass has attracted the attention of many observers, some of whom are "true believers" in one power or another (McNab submitted ${ }^{2}$ ), but in such advocacy, they have uniformly ignored the residual variation around the mean curve. The difficulty with that decision is that the fitted power changes, often

\footnotetext{
${ }^{1}$ This inquiry is a tribute to Mario Rosenmann, who I first met in 1959 when I was a graduate student on an expedition from the University of Wisconsin to study highaltitude adaptation of mammals indigenous to Chile and Perú. Mario and I worked together both in and around Santiago. I dedicate this article to Mario with the fondest of memories of days long gone.

${ }^{2}$ McNAB BK (manuscript) The evolution of energetics in birds and mammals.
}

significantly, as factors other than mass are incorporated into the analysis ( $\mathrm{McNab}$ submitted $^{3}$ ). I find the quest for the factors influencing the residual variation in BMR to be a much more biologically interesting and feasible goal. The causes for the residual variation have been and continue to be the subject of an extended controversy, as have been its consequences. Little of residual variation reflects measurement error.

Factors other than body mass that have been suggested to influence BMR have included food habits, climate, latitude, altitude, a commitment to burrowing or arboreal habits, presence on islands or continents, type of reproduction, etc. These factors, however, are often correlated with each other, so that their individual effects are difficult to circumscribe. Some observers have argued that the principal factor influencing the residual variation in BMR is "phylogeny". Phylogeny then acts as a "collective" for the various interactive factors other than body mass that influence BMR.

The variability around the mean fitted BMR-mass curve itself varies among groups of endotherms. For example, within the sample of 320 mammals, 272 eutherians showed a residual variation in total BMR of $4.4 \%$, identical to that found in the entire sample (McNab 1988a). However, body mass accounted for $98.8 \%$ of the variation in total BMR in 46 marsupials, i.e., the residual variation was only $1.2 \%$, or $27 \%$ of the eutherian value. This difference between eutherians and marsupials was also found by Hayssen \& Lacy (1985) in an earlier, but not identical, sample of 248 eutherians and 42 marsupials. Body mass thus is a more complete determinant of BMR in marsupials than in eutherians.

Another difference between marsupials and eutherians that has long been known is that marsupials have lower basal rates (Martin 1902, MacMillen \& Nelson 1969, Dawson \& Hulbert 1970, McNab 1978, 1986, Hayssen \& Lacy 1985). That conclusion, however, is misleading, reflecting as it does the means of the two groups, not the BMR of individual species. In fact, the lowest basal rates,

\footnotetext{
${ }^{3}$ McNAB BK \& HI ELLIS (manuscript) Flightless rails endemic have lower energy expenditures than flighted rails on islands and continents.
} 
corrected for body mass, found in eutherians are less than the lowest rates found in marsupials (Fig. 1). The actual difference that exists between these groups is that a few marsupials have marginally high basal rates by general mammalian standards, whereas many eutherians have exceedingly high basal rates that raise the collective average for eutherians above that of marsupials.

Earlier analyses of marsupial basal rates were limited by the number of species studied and by the technical tools available at the time for the analysis of the factors with which BMR was correlated. With the addition of data and the use of newer analytical tools, the variation in marsupial BMR can be reconsidered to determine the extent to which it varies with factors other than body mass. Such an analysis will permit me to reexamine whether a difference in BMR exists between marsupials and eutherians, and if so, why. I then shall examine the consequences of any differences in metabolism between these groups.

\section{MATERIAL AND METHODS}

Data on the BMR and body mass of marsupials were obtained from the literature (see Table 1), supplemented by unpublished data on four species of cuscuses (Phalanger) that I measured in Papua New Guinea. Whereas my earlier analyses (McNab 1978, 1988a) had data from 38 and 46 species, respectively, now data are available from 71 species, including such distinctive genera as Dromiciops, Phalanger, Tarsipes, Notoryctes, and Acrobates, from six of seven orders and 17 of 18 families, i.e., for all groups except the Caenolestidae in the Paucituberculata. These data are combined with

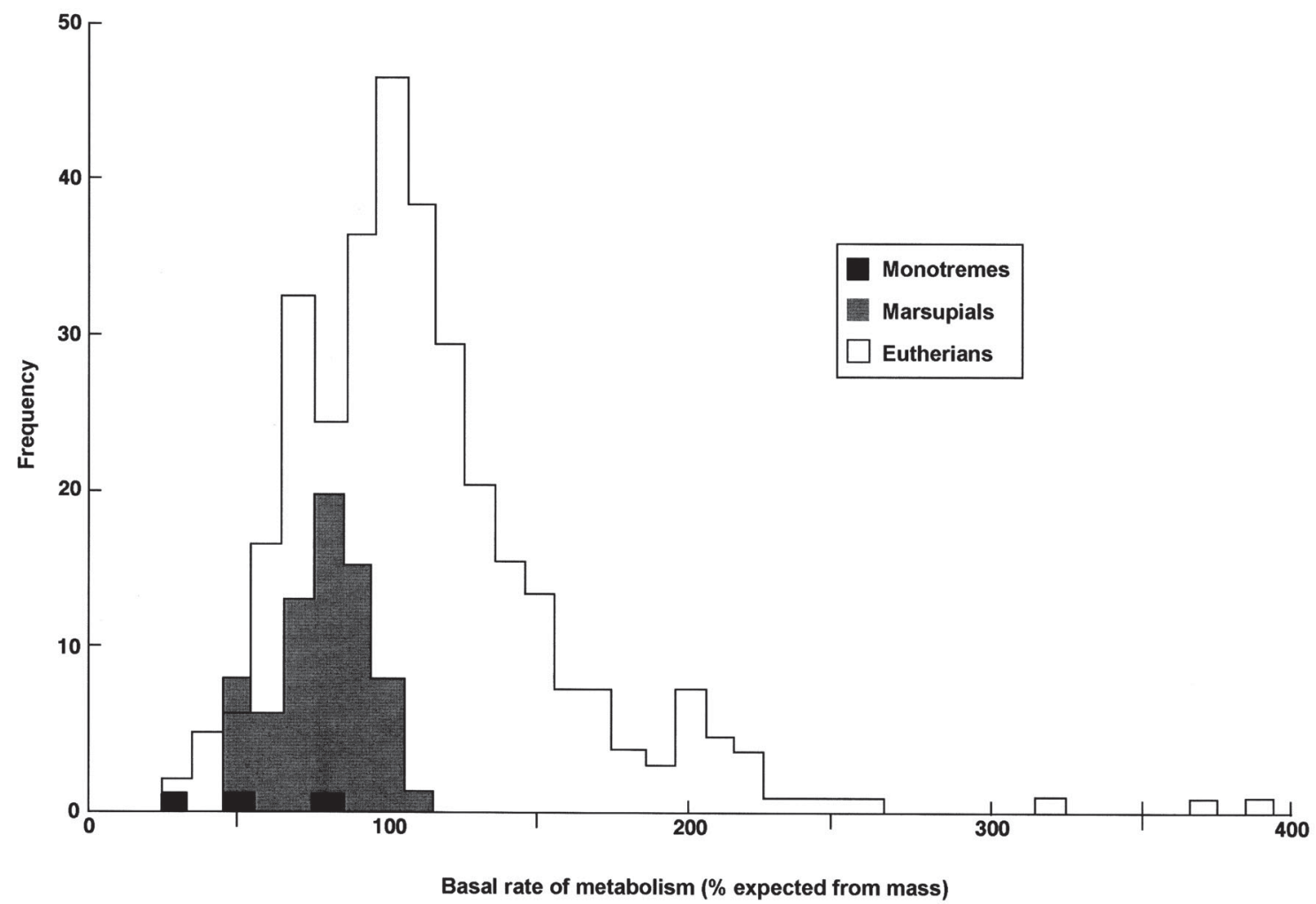

Fig. 1: Frequency distribution of basal metabolic rate (BMR) in marsupials (see Table 1) and eutherians (from McNab 1988a), expressed as a percentage of the values expected from body mass in the general mammal curve derived from McNab (1988a).

Distribución de frecuencia de tasa metabólica basal (BMR) en marsupiales (véase Tabla 1) y euterios (de McNab 1988a), expresadas como porcentaje de lso valores esperados para la masa corporal de la curva general de mamíferos de McNab (1988a). 
the qualitative characteristics of each species and the environments in which they live (Table 1), including food habits (carnivory, insectivory, frugivory, nectarivory, sap-eating, grazing, folivory, omnivory), substrate use (terrestrial, burrowing, arboreal, aquatic, terrestrial/arboreal), thermal climate (temperate, tropical, montane, temperate/ tropical), moisture climate (mesic, xeric), and whether they enter torpor (yes, no, hibernation).

These data are examined by the analysis of covariance (ANCOVA) with the program of SuperANOVA, Berkeley, California. This program permits one to regress $\log _{10} \mathrm{BMR}$ against $\log _{10}$ mass and to examine the maximal extent to which the residual variation is influenced by various species' characteristics and environmental factors, individually and in diverse combinations. This method also permits any interactive terms among the factors influencing BMR to be defined, as have been seen in arvicolid rodents (McNab 1992), New Zealand ducks (McNab 2003a), phyllostomid bats (McNab 2003b), and rails (McNab submitted $\left.{ }^{4}\right)$.

Another potential approach, phylogenetic contrasts, preferentially describes most (or all) of the residual variation in a character state to "phylogeny," thereby ignoring the interaction of character states (McNab 2003b). As noted, "phylogeny" at best acts as a collective for the various factors influencing the residual variation in character states. In fact, most relatives are physiologically similar because they have similar habits and live in similar environments, a condition seen in arvicolid rodents (McNab 1992), but when a radical ecological or behavioral diversification occurs in a clade, as in the family Phyllostomidae (McNab 2003b), it is associated with a diversification in physiology, which is what is to be expected. The most interesting question here, which will not be addressed in this article (but see $\mathrm{McNab}$, submitted ${ }^{5}$ ), is why some groups show a radical diversification, whereas others maintain a uniformity in size, behavior, physiology, and the environment occupied.

\footnotetext{
${ }^{4}$ McNAB BK (manuscript) Flightless rails endemic to islands have lower energy expenditures than flighted rails on continents.

${ }^{5}$ McNAB BK (manuscript) The evolution of energetics in birds and mammals.
}

\section{RESULTS}

Basal rate of metabolism in marsupials shows, as expected, a strong correlation with body mass (Fig. 2). The equation that describes this relationship is:

$$
\mathrm{VO}_{2}\left(\mathrm{~mL} \mathrm{O}_{2} \mathrm{~h}^{-1}\right)=2.31 \mathrm{~g}^{0.746}(1)
$$

where $\mathrm{g}$ is body mass in grams. This equation accounts for $98.8 \%$ of the variation in BMR $\left(\mathrm{F}_{1,68}=5511.35, \mathrm{P}<0.0001\right)$. Data from the honey 'possum (Tarsipes rostratus) were not used. This decision was made because the data were quite variable (see Withers et al. 1990); they represent by far the highest BMR (163\% of the general mammalian curve), independent of body mass, reported in any marsupial. A similar situation existed with the yapok (Chironectes minimus), a Neotropical semi-aquatic marsupial. I (McNab 1978) had reported that its BMR equaled $120 \%$ of the value expected from mammals generally, making it by far the highest basal rate measured in a marsupial at that time. Later, Thompson (1988) reported that the yapok had a basal rate that was average for a marsupial (97\%) and low for a mammal (82\%). I do not know why my measurements were higher than those of Thompson, but as long as temperature regulation occurs, most erroneous measurements of basal rate are likely to be high, due either to activity or anxiety. Therefore, I should like to see a reexamination of the honey "possum with special attention paid to the zone of thermoneutrality, which is narrow and difficult to define in a $10-\mathrm{g}$ species, especially if it is prone to activity.

With regard to the remaining 70 species, only $1.2 \%$ of the variation in marsupial basal rates is unaccounted for by equation (1), an observation similar to that seen before. Corrected for body size, the lowest BMR was found in the wombat Lasiorhinus latifrons (57 $\%$ of the mean marsupial curve), whereas the highest basal rate by marsupial standards (excluding Tarsipes) was found in the brushtailed rat-kangaroo Bettongia penicillata (131 $\%)$. The rat-kangaroo thus has a BMR that is only $2.3(=131 / 57)$ times that of the wombat, adjusted for the difference in body mass, whereas in eutherians this ratio can be much larger. For example, the bighorn sheep (Ovis canadensis $)$ has a basal rate that is $5.6(=224 /$ 40) times that of the giant armadillo 


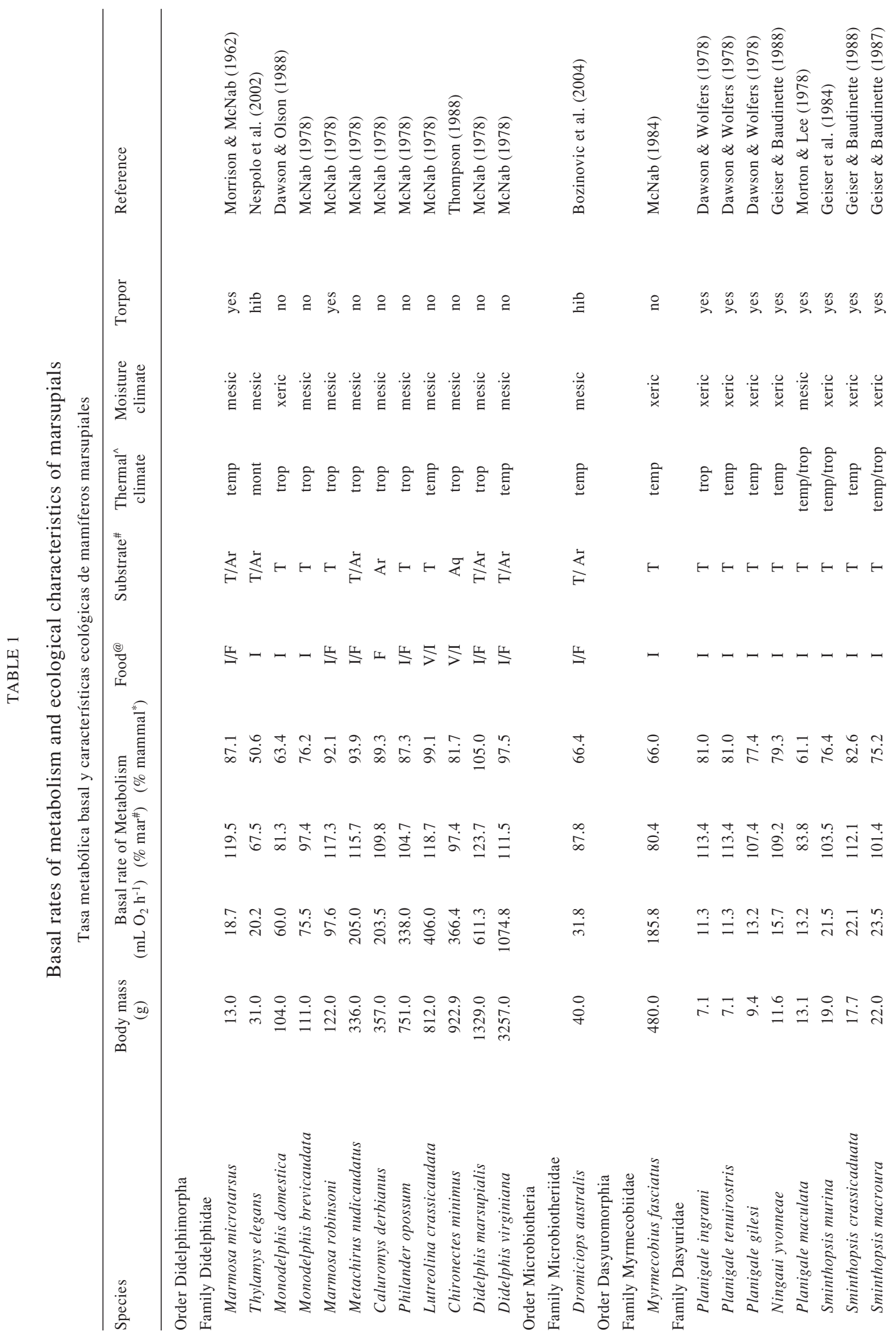




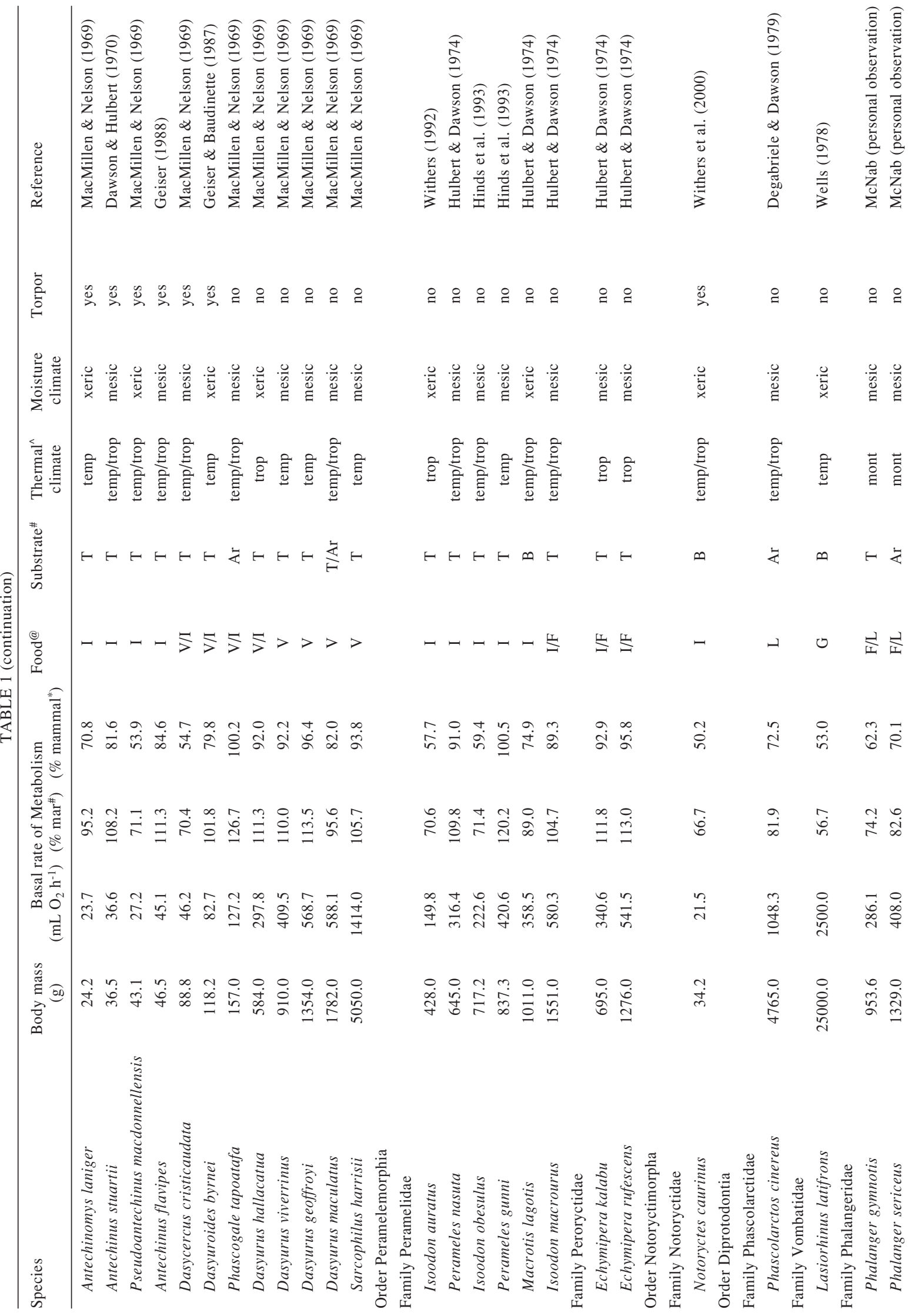




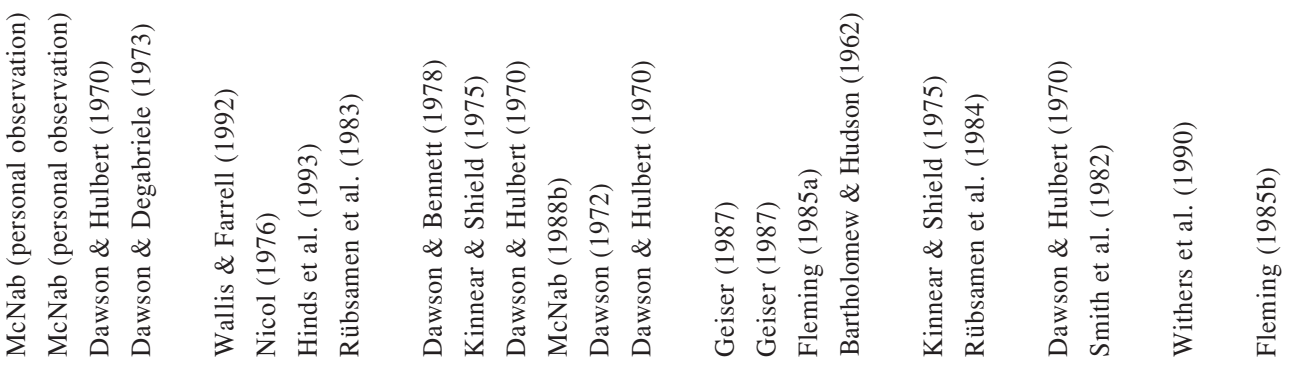

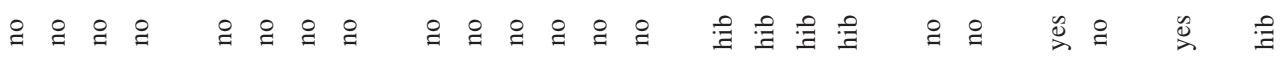

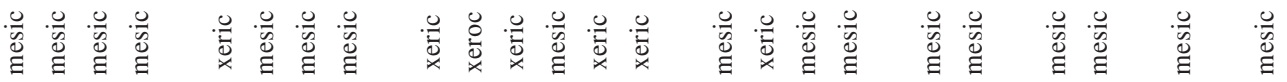

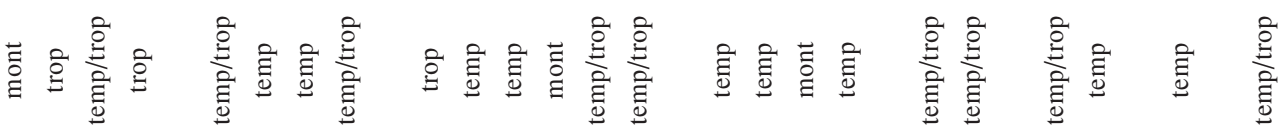

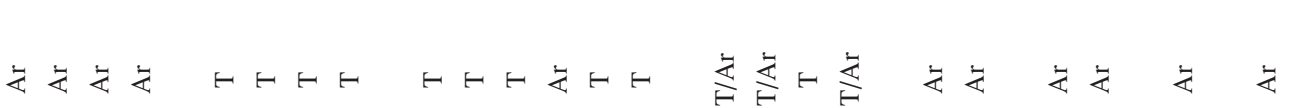

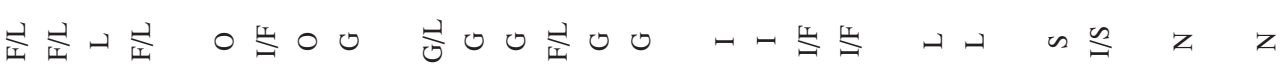

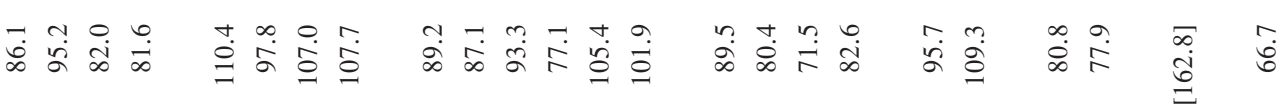

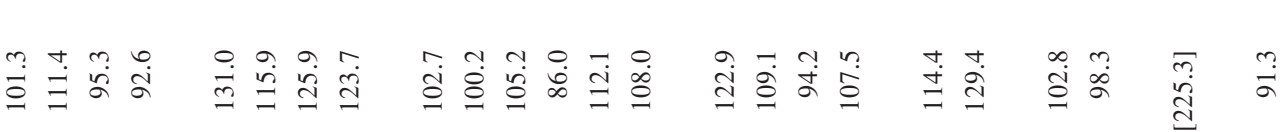

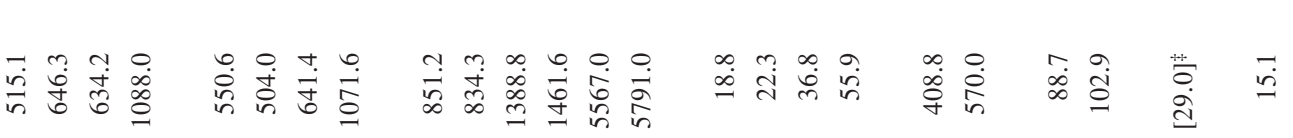

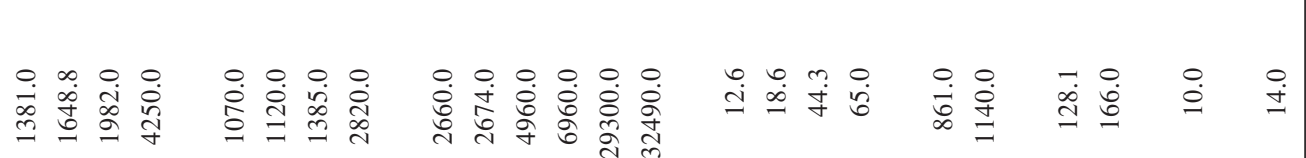

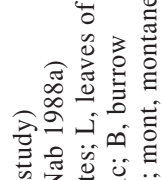

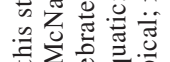

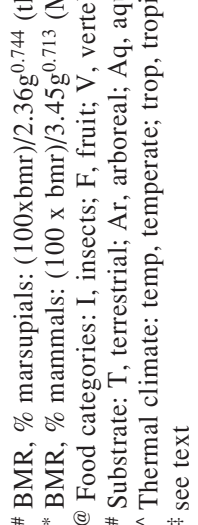




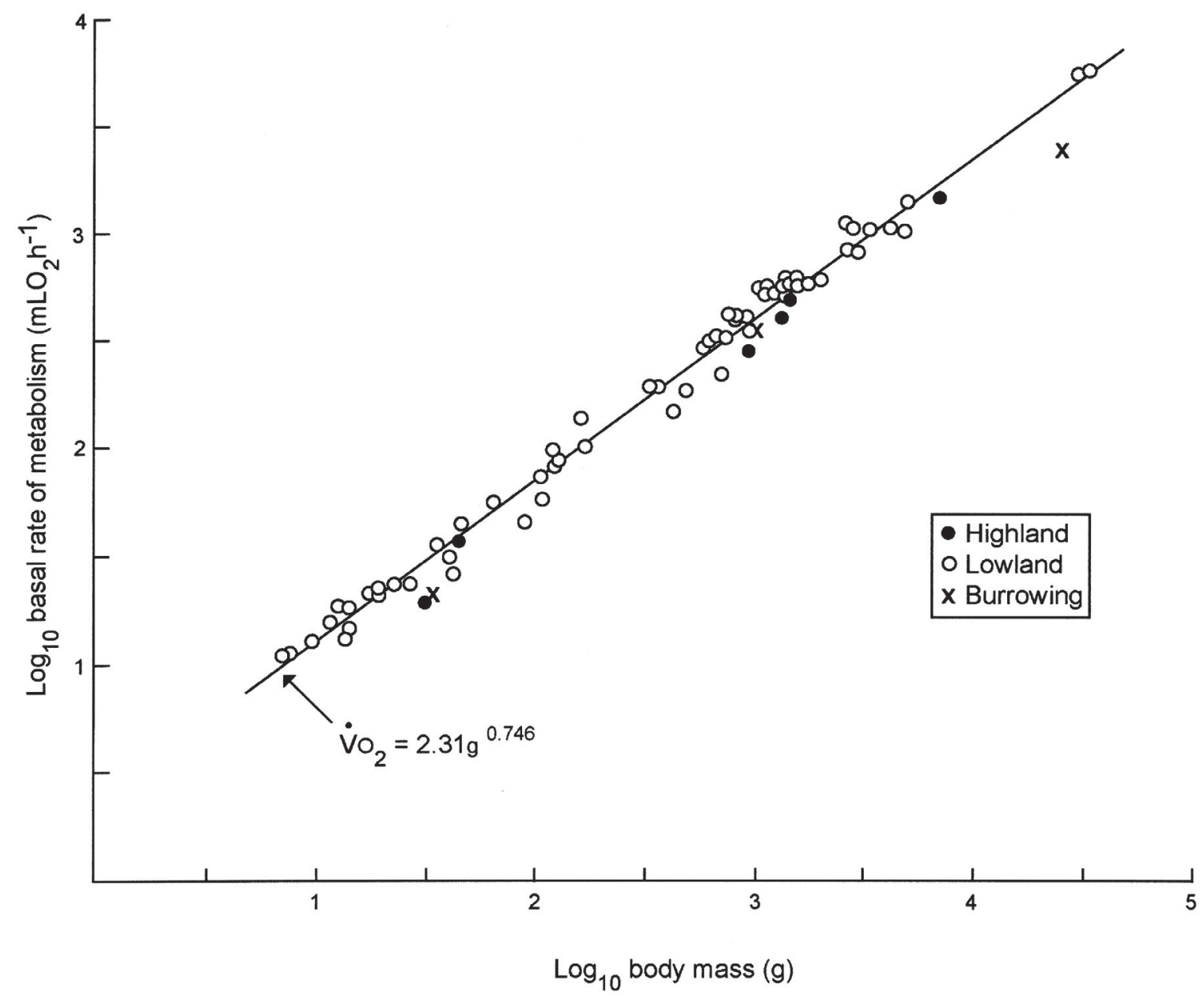

Fig. 2: $\log _{10}$ basal metabolic rate (BMR) in marsupials as a function of $\log _{10}$ body mass. The data are derived from Table 1.

$\log _{10}$ de la tasa metabólica basal (BMR) en marsupiales como función de $\log _{10}$ de la masa corporal. Los datos provienen de la Tabla 1.

(Priodontes maximus) (see McNab 1988a), using eutherian standards, while ignoring the even higher basal rates found in marine eutherians, like sea otters, seals, and porpoises, which would bring the ratio up to 9.7 (using data [388\%] from the sea otter [Enhydra lutris])! Again, much more residual variation in BMR is present in eutherians than in marsupials.

The impact of factors other than body mass on BMR in marsupials was examined, although, given the small residual variation, extensive correlations would appear to be unlikely. Indeed, $\log _{10}$ BMR was not correlated with the use of torpor $\left(\mathrm{F}_{2,66}=1.15, \mathrm{P}=0.32\right)$, food habits $\left(\mathrm{F}_{11,57}=1.25, \mathrm{P}=0.27\right)$, order affiliation
$\left(\mathrm{F}_{5,63}=1.33, \mathrm{P}=0.26\right)$, or occurrence in climates characterized by moisture $\left(\mathrm{F}_{1,67}=\right.$ $3.69, \mathrm{P}=0.059$ ), when individually coupled with $\log _{10}$ mass.

$\log _{10}$ BMR correlated with several factors in a complicated manner. For example, it correlated with substrate $\left(\mathrm{F}_{4,64}=3.87, P=\right.$ 0.0070 ), when substrate was represented by five categories and combined with $\log _{10}$ mass. However, only one category, burrowers, differed $\left(\mathrm{t}_{4,64}=-3.72, \mathrm{P}=0.0004\right)$ from the others, so when substrate use was divided into burrowers and non-burrowers, $\log _{10} \mathrm{BMR}$ correlated with substrate $\left(\mathrm{F}_{1,67}=15.47, \mathrm{P}=\right.$ $0.0002)$ and $\log _{10}$ mass $\left(\mathrm{F}_{1,67}=6678.58, \mathrm{P}<\right.$ $\left.0.0001 ; r^{2}=0.990\right) . \log _{10}$ BMR also correlated 
$\left(\mathrm{F}_{3,65}=3.03, \mathrm{P}=0.036\right)$ with the thermal climate in which marsupials live, when climate was represented by four categories (temperate, tropical, montane, or temperate/tropical) and combined with $\log _{10}$ mass. $\log _{10}$ BMR in montane species, defined as tolerating altitudes $>2000 \mathrm{~m}$, differed $\left(\mathrm{t}_{4,65}=2.58, \mathrm{P}=0.012\right)$ from that of the other categories, which did not differ from each other. So, when thermal climates other than montane were lumped into a lowland category, $\log _{10}$ BMR correlated $\left(\mathrm{F}_{1,67}=7.27, \mathrm{P}=0.0089\right)$ with thermal climate, when coupled with $\log _{10}$ mass $\left(F_{1,67}=\right.$ 6022.32, $\left.\mathrm{P}<0.0001 ; \mathrm{r}^{2}=0.989\right)$. When these factors were combined, $\log _{10}$ basal rate then correlated with thermal climate $\left(\mathrm{F}_{1,66}=11.30\right.$, $\mathrm{P}=0.0013)$, substrate $\left(\mathrm{F}_{1,66}=19.84, \mathrm{P}<\right.$ $0.0001)$, and $\log _{10}$ mass $\left(\mathrm{F}_{1,66}=7710.05, \mathrm{P}<\right.$ $\left.0.0001 ; r^{2}=0.992\right)$. This relationship takes the form of an equation:

$$
\mathrm{VO}_{2}\left(\mathrm{~mL} \mathrm{O}_{2} \mathrm{~h}^{-1}\right)=1.86(\mathrm{~A} \cdot \mathrm{S}) \mathrm{g}^{0.752}
$$

where $A$ is a non-dimensional coefficient for altitude equaling 1.25 in lowland species and 1.00 in montane species, and $S$ is a nondimensional coefficient for substrate equaling 0.66 for burrowing species and 1.00 for nonburrowers (Fig. 3). The coefficient in equation (2) would equal $1.53(=1.86 \times 1.25 \times 0.66)$ in lowland, burrowing marsupials and 1.86 (= $1.86 \times 1.00 \times 1.00$ ) in highland, non-burrowers. Ambient temperature and substrate, however, collectively accounted for only one-third $(0.4 \%)$ of the residual variation in equation (1) and leaves the remainder unaccounted for.

Burrowing eutherians are known to have low basal rates (McNab 1966, Contreras \& McNab 1990), so it is not surprising to see this pattern in marsupials. That basal rates in lowland marsupials are higher than in montane species is somewhat surprising because highland arvicolid rodents (McNab 1992), phyllostomid bats (McNab 2003b), and pteropodid bats (McNab \& Bonaccorso 2001) have higher basal rates than lowland species. However, highland tropical pigeons have lower basal rates than lowland species ( $\mathrm{McNab}$ 2000a). Among the six montane marsupials studied, only Phalanger carmelitae had a typical BMR by marsupial standards (101\%), whereas the remaining five had basal rates between 68 and $94 \%$.
Residual variation is reduced to $0.4 \%$ when familial $\left(\mathrm{F}_{12,47}=4.17, \mathrm{P}=0.0002\right)$ and ordinal $\left(\mathrm{F}_{1,47}=4.61, \mathrm{P}=0.037\right)$ affiliation are combined with temperature $\left(\mathrm{F}_{3,47}=7.44, \mathrm{P}=\right.$ $0.0004)$, moisture $\left(\mathrm{F}_{1,47}=5.76, \mathrm{P}=0.020\right)$, and $\log _{10}$ mass $\left(\mathrm{F}_{1,47}=3122.35, \mathrm{P}<0.0001 ; \mathrm{r}^{2}=\right.$ 0.996). Order affiliation appears and disappears depending on how the thermal climate is categorized. Familial affiliation, which appears consistently, is a "dummy" variable, probably coding for substrate, which is always excluded when family is included in the analysis, and possibly for other information. Obviously, factor interaction in the determination of marsupial BMR is complex.

\section{DISCUSSION}

Four aspects of marsupial basal rates remain the same: they (1) collectively show little variation independent of body mass, (2) average lower than in eutherians, (3) show no correlation with food habits, and (4) are not high by general mammalian standards. Marsupials fail to show a correlation of BMR with food habits principally because marsupial carnivores and grazers, unlike their eutherian counterparts, do not have higher basal rates than marsupials with other food habits.

With regard to the general absence of high basal rates in marsupials, only six species have marginally high basal rates by general mammalian standards (Table 1): Bettongia penicillata $(110 \%)$, Petauroides volans $(109 \%)$, Aepyprymnus rufescens (108\%), B. gaimardi (107\%), Macropus robustus (105\%), and Didelphis marsupialis (105\%). Many eutherians have much higher basal rates, compared to a general mammalian standard: of 272, 112 had basal rates between 100 and 150 $\%, 26$ between 150 and $200 \%, 11$ between 200 and $300 \%$, and three $>300 \%$ (McNab 1988a). The principal difference in the BMR of marsupials and eutherians, then, remains the same: compared to eutherians, marsupials have a truncated distribution of basal rates, corrected for body mass (Fig. 1).

\section{Causes}

These observations raise the question: why do eutherians have a greater diversity in BMR than 
is found in marsupials? To state that the difference is due to 'phylogeny' obfuscates the true factors responsible for this difference. One conclusion, however, is obvious: the high basal rates of eutherians are not related to the cost of endothermy, except possibly in the coldest environments and at the smallest masses (Lillegraven et al. 1987): marsupials collectively are not poorer thermoregulators than eutherians. Although eutherians with unusually low basal rates often show marginal to poor thermoregulation, e.g., Heterocephalus glaber (McNab 1966), the only marsupial known to have marginal temperature regulation is the mole Notoryctes caurinus (Withers et al.
2000), which combines a low basal rate $(50 \%$ of the mammalian standard) with a small mass $(34 \mathrm{~g})$. Other marsupials that combine a small mass with a low basal rate enter a regulated torpor (Bartholomew \& Hudson 1962, Morrison \& McNab 1962, Dawson \& Wolfers 1978, Fleming 1985a, 1985b, Geiser et al. 1984, Geiser 1987, 1988, Geiser \& Baudinette 1987, 1988, Withers et al. 1990), similar to the situation in white-toothed shrews (Crocidurinae; Genoud 1988). Small eutherians that avoid torpor, most notably red-toothed shrews belonging to the subfamily Soricinae and arvicolid rodents, "overcompensate" metabolism by conforming to the "boundary

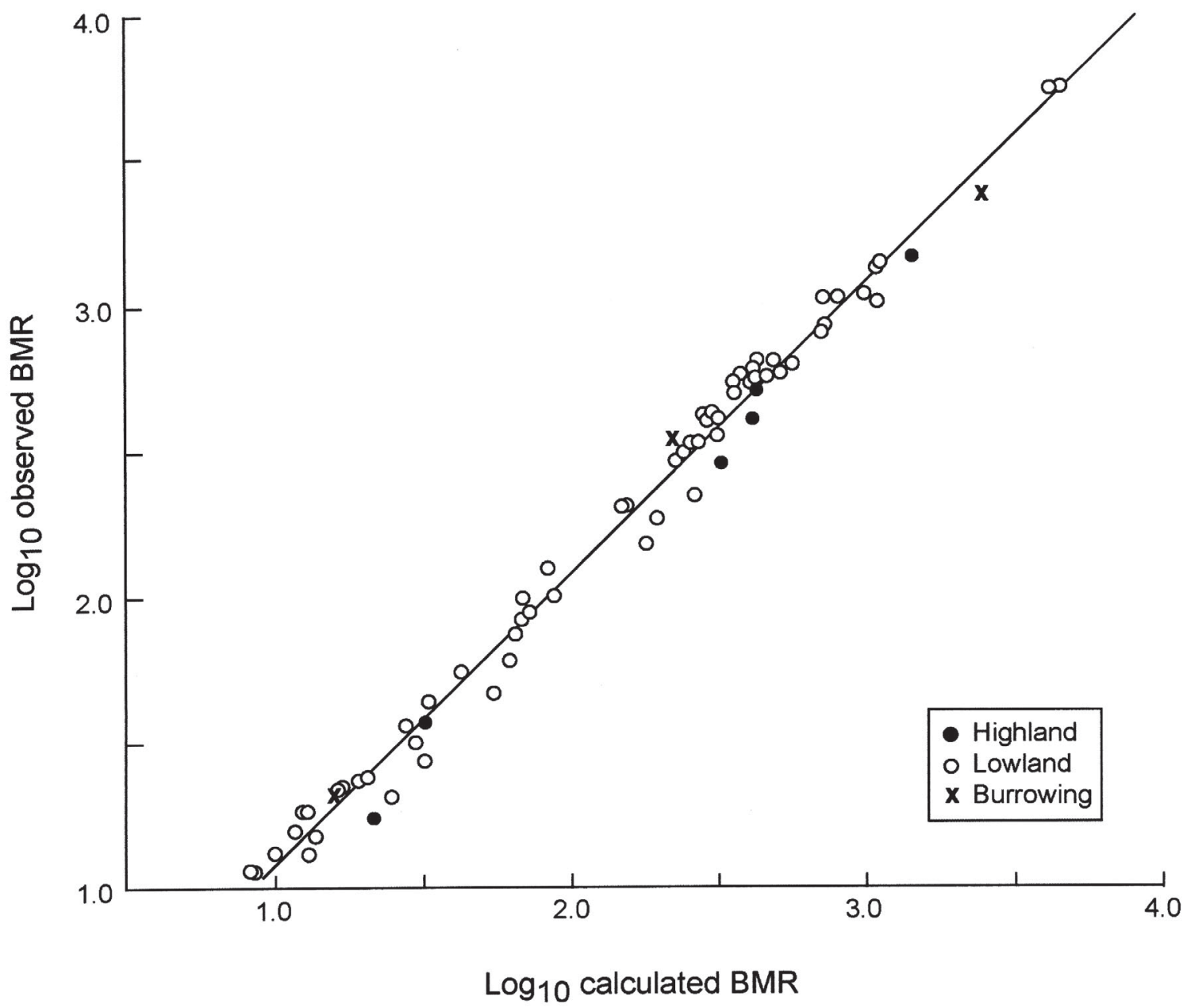

Fig. 3: $\log _{10}$ observed basal metabolic rate (BMR) in marsupials as a function of $\log _{10}$ BMR based on equation (2), which takes body mass, altitudinal distribution, and burrowing or non-burrowing habits into consideration.

$\log _{10}$ de la tasa metabólica basal (BMR observada en marsupiales como función de $\log _{10}$ de BMR basado en la ecuación (2), que considera la masa corporal, la distribución altitudinal y los hábitos subterráneos o no subterráneos 
curve' for continuous endothermy (McNab 1983, 1992). Small dasyurids, burramyids, and among eutherians crocidurines do not show this response. Consequently, the high basal rates of eutherians, except at the smallest masses, must be related to some factor other than the cost of endothermy.

What can this factor be? I (1986) suggested that it reflected a difference in the energetics of reproduction: high basal rates of metabolism in eutherians facilitate an increased rate of reproduction, which partly results from having a placenta, developed from embryonic (trophoblastic) and maternal tissues, that permits an augmented rate of exchange between a gravid eutherian and her developing offspring without an immunological rejection of the genetically distinct offspring (Lillegraven 1976, Parker 1977, Lillegraven et al. 1987).

In eutherians gestational period decreases and the post-natal growth rate, fecundity, and the amplitude of population cycles increase with an increase in BMR, corrected for body size (McNab 1980, Stephenson \& Racey 1995, N. Vasey \& D.T. Rasmussen personal communication). Milk production (Glazier 1985, McLean \& Speakman 2000) and litter size (Genoud 1988) also increase with BMR in eutherians, but for complications, especially in species with low basal rates, see Thompson (1991). Rasmussen \& Izard (1988) showed in the Lorisidae that variation in basal rate accounted for much of the variation in gestational period, lactational period, and postnatal growth constant. That is, a high BMR in eutherians facilitates an increased reproductive output, which occurs whenever the resources in the environment permit an increase in rate of metabolism, most notably in carnivores and grazers. External circumstances, such as the uncertain availability or low quality of food, however, may force eutherians to have low basal rates with its consequence, a reduced reproductive output, especially in frugivores, folivores, and large terrestrial invertebrateeaters.

The reproductive rate of marsupials does not increase with BMR at least in part because nutritional and waste exchange cannot be increased between a pregnant female and her developing young in the absence of a trophoblast without the risk of immunological rejection. Most of the embryological development in marsupials occurs in the presence of a shell membrane that isolates the embryos from maternal tissues, thereby protecting the fetuses from immunological rejection, but restricting fetal-maternal exchange. The limited marsupial in utero development depends on the presence of a large egg yolk mass, which is nearly absent in eutherians (Parker 1977). The independence of reproduction from basal rate is responsible for the restricted range of residual variation in BMR in marsupials (McNab 1986).

Although marsupials cannot augment nutrient transfer to intrauterine embryos, they theoretically could facilitate the postpartum growth and development of their young through an increase in rate of metabolism during lactation. However, at birth marsupial young, compared to eutherians, are still at an embryonic stage of development. Their postnatal rate of development is low, which may be limited by a restricted uptake and processing of milk as a result of the delayed development of digestive, respiratory, and excretory systems (Parker 1977). Although the increase in rate of metabolism in marsupials during lactation may be appreciable (Thompson \& Nicoll 1986), especially given their generally low basal rates, it still is less than that found in lactating eutherians with high basal rates (Fig. 10.2 of Thompson 1992). This may explain why the conceptual-to-weaning periods in marsupials average 1.5 times those of eutherians of equal mass (Thompson 1987), most of the difference reflecting the length of the lactational period. So, in spite of having food habits, such as carnivory and grazing, that permit high basal rates in eutherians, marsupial carnivores and grazers have low to intermediate basal rates by general mammalian standards. Variation in marsupial BMR is therefore principally associated with the cost of thermoregulation, which varies with body mass. Variation in the rate of reproduction occurs among marsupials (Parker 1977, Russell 1982), but it is not correlated with residual variation in BMR (McNab 1986).

\section{Consequences}

The difference in energy expenditure between marsupials and eutherians appears to have at 
least two ecological consequences: (1) the restricted tolerance of marsupials to cold environments and (2) the limited ability of marsupials to coexist with eutherians.

Endotherms encounter cold environments in mid-latitudes at high altitudes and seasonally at high latitudes. The two extended mountainous regions with marsupials are New Guinea and South America. In New Guinea several marsupials are found near the equator at altitudes between 3,500 and 4,000 m, including two bandicoots, one macropod, two phalangers, and two pseudocheirids, whereas three rodents extend to 4,000-4,500 m (Flannery 1995). In tropical South America the only marsupials that get to $3,500 \mathrm{~m}$ or higher are caenolestids, including Lestoros and possibly Caenolestes (Eisenberg 1989, Eisenberg \& Redford 1999). Eutherians, in contrast, are found at much higher altitudes in South America: eight rodents, the vicuña, and Felis jacobita reach a high-altitude limit between 4,500 and 5,000 m, and Felis colocolo, Puma, Akodon, and Lagidium occur at altitudes greater than 5,000 m (Redford \& Eisenberg 1989, Eisenberg \& Redford 1999). Marsupials also are less tolerant than eutherians of cold-temperate environments in North America, where only one species (Didelphis virginiana) is found north of México (see Brocke 1970), and in South America, where only Lestodelphus halli, possibly a hibernator, enters southern Patagonia (McNab 1982, Redford \& Eisenberg 1989). No marsupial resides on Tierra del Fuego.

The restricted distribution of marsupials in cold environments may reflect their response to altitude in New Guinea, a reduction in BMR. Unfortunately, the basal rates of caenolestids have not been measured, but $C$. obscurus has a typically low marsupial body temperature (35.4 ${ }^{\circ} \mathrm{C}, \mathrm{McNab}$ 1978), which suggests that it too has a basal rate that is low by mammalian standards. Didephis virginiana, the only marsupial in temperate North America, has a basal rate near that expected from general mammalian standards (98\%), when measured in subtropical Florida (McNab 1978), but it appears to be lower $(52-56 \%)$ at the northern limits of distribution in Michigan (Brocke 1970), a pattern similar to the reduction in highland marsupials in PNG. A low basal rate undoubtedly limits the tolerance of $D$. virginiana to cold temperatures, a response that is counteracted by its rather large mass, which facilitates winter survival in adults through seasonal fat storage (Brocke 1970). Dromiciops australis, which is limited to temperate Chile and adjacient Argentina, has a basal rate that is only $66 \%$ of the mammalian level, and Thylamys elegans in temperate Chile has a basal rate that is only $51 \%$. In contrast, coldtemperate and polar eutherians, such as arvicolid rodents, hares, carnivores, and ungulates, are characterized by high basal rates.

The coexistence of marsupials with eutherians is limited. Their apparent coexistence in the New World is misleading in that most Neotropical marsupials feed principally on fruit, insects, or a mixture of fruit and insects. This is a highly restricted range of diets compared to that found in Australian marsupials, which collectively feed on insects, vertebrates, fruit, nectar, sap, leaves, and grass. A mixture of insects and fruits is a diet associated with low basal rates in eutherians. For example, the kinkajou (Potos flavus), an arboreal eutherian that feeds heavily on fruit, has a BMR that is $87 \%$ of the value expected from mammals, which is similar $(89 \%)$ to that of a Neotropical marsupial with similar habits, Caluromys derbianus. These basal rates reflect their arboreal, frugivorous habits, as has been seen in other eutherians with similar habits, such as various viverrids (McNab 1995), when basal rates varied from 63-87\% of the mammalian value.

Marsupial carnivores and grazers do not coexist with eutherians that have these food habits. Marsupials with these habits are limited to greater Australia, where the only terrestrial eutherians are bats and murid rodents. The only possible marsupial carnivore in the Neotropics is Lutreolina crassicaudata, which has been described to prey "...on small vertebrates, fishes, and insects" (Redford \& Eisenberg 1989, p. 23); it has a BMR equal to $99 \%$ of the general mammal curve, which is similar to that found in some omnivorous canids. The Australian marsupials committed to carnivory have basal rates that varied from 82 to $96 \%$ of the value expected from mammals generally (Table 1), whereas nine eutherian, terrestrial carnivores have basal rates that vary from 116 to $231 \%$ (McNab 1988a) and recent measurements on seven terrestrial, carnivorous felids reported basal rates between 123 to $151 \%$ (McNab 2000b). 
Marsupial carnivores evolved in the absence of eutherian carnivores at least twice, once in Australia/Tasmania/New Guinea, and independently in island South America. About 3,500 years ago, a semi-domesticated form of the wolf, the dingo (Canis lupus [dingo]), was brought to Australia by seafaring Asians (Corbett 1995). Thereafter, indigenous Australian marsupial carnivores, including the thylacine (Thylacinus cynocephalus), Tasmanian devil (Sarcophilus harrisii), and eastern quoll (Dasyurus viverrinus), became extinct on mainland Australia, although they were able to survive on Tasmania in the absence of the dingo. The recent reduction in the geographic range on Australia of the western quoll (D. geoffroii), spotted-tailed quoll (D. maculatus), and kowari (Dasyuroides byrnei) (Strahan 1983) also may have resulted from competition with eutherian carnivores introduced by humans.

The eutherian ability to maximize reproductive output through an increase in energy expenditure may have permitted the dingo to displace marsupial carnivores. It may also explain how the canids and felids invading from North America with the establishment of the Panamanian land bridge were able to displace carnivorous marsupials, such as thylacosmilids, indigenous to South America. The Neotropical marsupials that survived the invasion were those that had habits that prevented ecologically similar eutherians from having high rates of metabolism and high rates of reproduction, i.e., fruit- and insect-eating in various combinations.

The demonstration in Australia that marsupial carnivores became extinct or had a reduced distribution in association with the introduction of eutherian carnivores raises the question why a similar impact has not been seen in Australian marsupial grazers with the importation of cattle and sheep, given that a difference in BMR between marsupial (87 to $108 \%$ of mammalian standard, excluding the burrowing wombat) and eutherian grazers (118 to $237 \%$ ) is similar to that found in carnivores. Large macropods may withstand the presence of the domesticated grazers as a result of their adjustments to life in xeric environments, whereas cattle and sheep depend on humans to supply water in much of central Australia. An importation of desert ungulates into central Australia might represent a greater threat to macropods. Indeed, the survival of dromedary camels (Camelus dromedarius) in central Australia has been marked (Strahan 1983), although without any clear impact on macropods.

Early investigators, including Huxley (1880) and Martin (1902) suggested that marsupials were evolutionarily intermediate between monotremes and eutherians, and some recent workers, including Lillegraven (1976), Pond (1977), Morton et al. (1982), Russell (1982), McNab (1986), and Lillegraven et al. (1987), have pointed out some of the limitations of the marsupial mode of reproduction. This led some (Kirsch 1977a, 1977b, Parker 1977, Low 1978, Hayssen et al. 1985) to defend marsupials as being at least equivalent to eutherians, and possibly their superior in unpredictable, especially xeric, environments (Parker 1977, Low 1978), but see Morton et al. (1982) and Thompson (1987). Part of this difference in opinion is based on the tendency to be preoccupied with the reproduction of macropods at the expense of other marsupials (Russell 1982, Morton et al. 1982).

The analysis given here points out that marsupials are the equivalent of eutherians under some circumstances, namely in warmtemperate and tropical environments when they have food habits that require eutherians to abandon their reproductive advantage. Marsupials, however, have a difficult task tolerating cold environments under all circumstances and cannot tolerate the presence of eutherians even in warm environments when marsupials have food habits that permit eutherians to have high rates of metabolism and therefore high rates of reproduction. Are marsupials competitively inferior to eutherians? Yes, under some circumstances.

\section{ACKNOWLEDGMENTS}

I thank Francisco Bozinovic for the invitation to contribute to this tribute to the life of Mario Rosenmann. Charles Woods thoughtfully read an earlier version of this manuscript. I also appreciate reading a manuscript by Natalia Vasey and D. Tab Rasmussen on the energetics of reproduction in lorisid primates. Philip Withers kindly responded to some questions that I had on the energy expenditure of Notoryctes and Tarsipes. 


\section{LITERATURE CITED}

BARTHOLOMEW GA \& JW HUDSON (1962) Hibernation, estivation, temperature regulation, evaporative water loss, and heart rate in the pygmy possum Cercartetus nanus. Physiological Zoology 35: 94-107.

BROCKE RH (1970) The winter ecology and bioenergetics of the opossum, Didelphis marsupialis, as distributional factors in Michigan. Ph.D. Dissertation, Department of Fisheries and Wildlife, Michigan State University, Ann Arbor, Michigan, USA. xiii +215 .

BOZINOVIC F (1992) Scaling basal and maximum metabolic rate in rodents and the aerobic capacity model for the evolution of endothermy. Physiological Zoology 65: 921-932.

BOZINOVIC F, G RUIZ \& M ROSENMANN (2004) Energetics and torpor of a South American“"living fossil," the microbiotheriid Dromiciops gliroides. Journal of Comparative Physiology B 174: 293-297.

CONTRERAS LC \& BK McNAB (1990) Thermoregulation and energetics in subterranean mammals. In: Nevo E \& OA Reig (eds) Evolution of subterranean mammals at the organismal and molecular levels: 231-250. Wiley-Liss, New York, New York, USA.

CORBETT L (1995) The dingo in Australia and Asia. Comstock/Cornell University Press, Ithaca, New York, USA. 197 pp.

DAWSON WR \& AF BENNETT (1978) Energy metabolism and thermoregulation of the spectacled hare wallaby (Lagorchestes conspicillatus). Physiological Zoology 51: 114-130.

DAWSON TJ (1972) Thermoregulation in Australian desert kangaroos. Symposium of the Zoological Society, London 31: 133-146.

DAWSON TJ \& R DEGABRIELLE (1973) The cuscus (Phalanger maculatus) —a marsupial sloth? Journal of Comparative Physiology 83: 41-50.

DAWSON TJ \& AJ HULBERT (1970) Standard metabolism, body temperature, and surface areas of Australian marsupials. American Journal of Physiology 218: 1233-1238.

DAWSON TJ \& JM OLSON (1988) Thermogenic capacities of the opossum Monodelphis domestica when warm and cold acclimated: similarities between American and Australian marsupials. Comparative Biochemistry and Physiology 89A: 85-91.

DAWSON TJ \& JM WOLFERS (1978) Metabolism, thermoregulation and torpor in shrew sized marsupials of the genus Planigale. Comparative Biochemistry and Physiology 59A: 305-309.

DEGABRIELLE R \& TJ DAWSON (1979) Metabolism and heat balance in an arboreal marsupial, the koala (Phascolarctos cinereus). Journal of Comparative Physiology 134: 293-301.

EISENBERG JF (1989) Mammals of the Neotropics: the northern Neotropics. University of Chicago Press, Chicago, Illinois, USA. $\mathrm{x}+449$ pp.

EISENBERG JF \& KH REDFORD (1999) Mammals of the Neotropics: the central Neotropics. University of Chicago Press, Chicago, Illinois, USA. $x+609$ pp.

FLANNERY $T$ (1995) Mammals of New Guinea. Comstock-Cornell University Press, Ithaca, New York, USA. 568 pp.

FLEMING MR (1985a) The thermal physiology of the mountain pygmy-possum Burramys parvus (Marsupialia: Burramyidae). Australian Mammalogy 8: 79-90.
FLEMING MR (1985b) The thermal physiology of the feathertail glider, Acrobates pygmaeus (Marsupialia: Burramyidae). Australian Journal of Zoology 33: 667-681.

GEISER F (1987) Hibernation and daily torpor in pygmy possums (Cercartetus spp., Marsupialia). Physiological Zoology 60: 93-102.

GEISER F (1988) Daily torpor and thermoregulation in Antechinus (Marsupialia): influence of body mass, season, development, reproduction, and sex. Oecologia 77: 395-399.

GEISER F, ML AUGEE, HCK McCARRON \& JK RAISON. (1984) Correlates of torpor in the insectivorous dasyurid marsupial Sminthopsis murina. Australian Mammalogy 7: 185-191.

GEISER F \& RV BAUDINETTE (1987) Seasonality of torpor and thermoregulation in three dasyurid marsupials. Journal of Comparative Physiology B 157: 335-344.

GEISER F \& RV BAUDINETTE (1988) Daily torpor and thermoregulation in the small dasyurid marsupials Planigale gilesi and Ningaui yvonneae. Australian Journal of Zoology 36: 473-481.

GENOUD M (1988) Energetics strategies of shrews: ecological constraints and evolutionary implications. Mammal Review 18: 173-193.

GLAZIER DS (1985) Relationship between metabolic rate and energy expenditure for lactation in Peromyscus. Comparative Biochemistry and Physiology 80A: 587-590.

HAYSSEN V \& RC LACY (1985) Basal metabolic rates in mammals: taxonomic differences in the allometry of BMR and body mass. Comparative Biochemistry and Physiology 81A: 741-754.

HAYSSEN V, RC LACY \& PJ PARKER (1985) Metatherian reproduction: transitional or transcending? American Naturalist 126: 617-632.

HINDS DS, RV BAUDINETTE, RE MacMILLEN \& EA HALPERN (1993) Maximum metabolism and aerobic factorial scope of endotherms. Journal of Experimental Biology 182: 41-56.

HULBERT AJ \& TJ DAWSON (1974) Standard metabolism and body temperature of perameloid marsupials from different environments. Comparative Biochemistry and Physiology 47A: 583-590.

HUXLEY TH (1880) On the application of the laws of evolution to the arrangement of the Vertebrata, and more particularly of the Mammalia. Proceedings of the Zoological Society of London 1880: 649-662.

KINNEAR A \& JW SHIELD (1975) Metabolism and temperature regulation in marsupials. Comparative Biochemistry and Physiology 52A: 235-246.

KIRSCH JAW (1972a) The six-percent solution: second thoughts on the adaptiveness of the Marsupialia. American Scientist 65: 276-288.

KIRSCH JAW (1972b) Biological aspects of the marsupial-placental dichotomy: a reply to Lillegraven. Evolution 31: 898-900.

KOTEJA P (1987) On the relation between basal and field metabolic rates in birds and mammals. Functional Ecology 5: 56-64.

LILLEGRAVEN JA (1976) Biological considerations of the marsupial-placental dichotomy. Evolution 29: 707-722.

LILLEGRAVEN JA, SD THOMPSON, BK McNAB \& JL PATTON (1987) The origin of eutherian mammals. Biological Journal of the Linnean Society 32: 281336.

LOW BS (1978) Environmental uncertainity and the parental strategies of marsupials and placental. American Naturalist 112: 197-213. 
MacMILLEN RE \& JE NELSON (1969) Bioenergetics and body size in dasyurid marsupials. American Journal of Physiology 217: 1246-1251.

MARTIN CJ (1902) Thermal adjustment and respiratory exchange in monotremes and marsupials-A study in the development of homoeothermism. Philosophical Transactions of the Royal Society of London B 195: 1-37.

McLEAN JA \& JR SPEAKMAN (2000) Effects of body mass and reproduction on basal metabolic rate of brown long-eared bats (Plecotus auritus) Physiological and Biochemical Zoology 73: 112-121.

McNAB BK (1966) The metabolism of fossorial rodents: a study of convergence. Ecology 47: 712-733.

McNAB BK (1978) The comparative energetics of Neotropical marsupials. Journal of Comparative Physiology 125: 115-128.

McNAB BK (1980) Food habits, energetics, and the population biology of mammals. American Naturalist 116: 106-124.

McNAB BK (1982) The physiological ecology of South American mammals. In: Mares MA \& $\mathrm{HH}$ Genoways (eds) Mammalian biology in South America: 187-207. Special Publications Series, Pymatuning Laboratory of Ecology, University of Pittsburgh, Pittsburgh, Pennsylvania, USA.

McNAB BK (1983) Energetics, body size, and the limits to endothermy. Journal of Zoology, London 99: 1-29.

McNAB BK (1984) Physiological convergence amongst ant-eating and termite- eating mammals. Journal of Zoology, London 203: 485-510.

McNAB BK (1986) Food habits, energetics, and the reproduction of marsupials. Journal of Zoology, London 208: 595-614.

McNAB BK (1988a) Complications in the scaling basal rate of metabolism in mammals. Quarterly Review of Biology 63: 25-54.

McNAB BK (1988b) Energy conservation in a treekangaroo (Dendrolagus matschiei) and the red panda (Ailurus fulgens). Physiological Zoology 61: 280-292.

McNAB BK (1992) The comparative energetics of rigid endothermy: the Arvicolidae. Journal of Zoology, London 227: 586-606.

McNAB, BK (1995) Energy expenditure and conservation in frugivorous and mixed-diet carnivorans. Journal of Mammalogy 76: 206-222.

McNAB BK (1997) On the utility of uniformity in the definition of basal rate of metabolism. Physiological Zoology 70: 718-720.

McNAB BK (2000a) The influence of body mass, climate, and distribution on the energetics of South Pacific pigeons. Comparative Biochemistry and Physiology 127A: 309-329

McNAB BK (2000b) The standard energetics of mammalian carnivores: Felidae and Hyaenidae. Canadian Journal of Zoology 78: 1-13.

McNAB BK (2003a) The energetics of New Zealand's ducks. Comparative Biochemistry and Physiology 135A: 229-247.

McNAB BK (2003b) Standard energetics of phyllostomid bats: the inadequacies of phylogenetic contrast analyses. Comparative Biochemistry and Physiology 135A: 357-368.

McNAB BK \& FJ BONACCORSO (2001) The metabolism of New Guinean pteropodid bats. Journal of Comparative Physiology B 171: 201-214.

MORRISON PR \& BK McNAB (1962) Daily torpor in a Brazilian murine opossum (Marmosa). Comparative Physiology and Biochemistry 6: 57-68.

MORTON SR \& AK LEE (1978) Thermoregulation and metabolism in Planigale maculata (Marsupialia: Dasyuridae). Journal of Thermal Biology 3: 117120.

MORTON SR, HF RECHER, SD THOMPSON \& RW BRAITHWAITE (1982) Comments on the relative advantages of marsupial and eutherian reproduction. American naturalist 120: 128-134.

NAGY KA (1994) Field bioenergetics of mammals: what determines field metabolic rates? Australian Journal of Zoology 42: 43-53.

NESPOLO RF, LD BACIGALUPE, P SABAT \& F BOZINOVIC (2002) Interplay among energy metabolism, organ mass and digestive enzyme activity in the mouse-opossum Thylamys elegans: the role of thermal acclimation. Journal of Experimental Biology 205: 2697-2703.

NICOL SC (1976) Oxygen consumption and nitrogen metabolism in the potoroo, Potorus tridactylus. Comparative Biochemistry and Physiology 55A: 215-218.

PARKER P (1977) An ecological comparison of marsupial and placental patterns of reproduction. In: Stonehouse B \& D Gilmore (eds) The biology of marsupials: 273-286. Macmillan Press, London, United Kingdom.

POND CM (1977) The significance of lactation in the evolution of mammals. Evolution 31: 177-199.

RASMUSSEN DT \& MK IZARD (1988) Scaling of growth and life history traits relative to body size, brain size, and metabolic rate in lorises and galagos (Lorisidae, Primates). American Journal of Physical Anthropology. 75: 357-367.

REDFORD KH \& JF EISENBERG (1989) Mammals of the Neotropics: the southern cone. University of Chicago Press, Chicago, Illinois, USA. 430 pp.

RÜBSAMEN K, ID HUME, WJ FOLEY \& RÜBSAMEN (1984) Implications of the large surface area to body mass ratio on the heat balance of the greater glider (Petauroides volans). Journal of Comparative Physiology 154: 105-111.

RÜBSAMEN U, ID HUME \& K RÜSAMEN (1983) Effect of ambient temperature on autonomic thermoregulation and activity patterns in the rufous rat-kangaroo (Aepyprymnus rufescens: Marsupialia). Journal of Comparative Physiology 153: $175-179$.

RUSSELL EM (1982) Patterns of parental care and parental investment in marsupials. Biological Reviews 57: 423-486.

SMITH AP, KA NAGY, MR FLEMING \& B GREEN (1982) Energy requirements and water turnover in free-living Leadbeater's possums Gymnobelideus leadbeateri (Marsupialia: Petauridae). Australian Journal of Zoology 30: 737-749.

SPEAKMAN JR (2000) The cost of living: field metabolic rates of small mammals. Advances in Ecological Research 30: 177-297.

STEPHENSON PJ \& PA RACEY (1995) Resting metabolic rate and reproduction in the Insectivora. Comparative Biochemistry and Physiology 112A: 215-223.

STRAHAN R (1983) Australian museum complete book of Australian mammals. Angus \& Robertson Publishers, Sydney, Australia, 530 pp.

THOMPSON SD (1987) Body size, duration of parental care, and the intrinsic rate of natural increase in eutherian and metatherian mammals. Oecologia 71: 201-209.

THOMPSON SD (1988) Thermoregulation in the water opossum (Chironectes minimus): an exception that "proves" a rule. Physiological Zoology 61: 450-460. 
THOMPSON SD (1992) Gestation and lactation in small mammals: basal metabolic rate and the limits of energy use. In: Tomasi TE \& TH Horton (eds) Mammalian energetics: interdisciplinary views of metabolism and reproduction: 213-259. Comstock/ Cornell University Press, Ithaca, New York, USA.

THOMPSON SD \& ME NICOLL (1986) Basal metabolic rate and energetics of reproduction in therian mammals. Nature 321: 690-693.

WALLIS IR \& DJ FARRELL (1992) Energy metabolism in potoroine marsupials. Journal of Comparative Physiology B 162: 478-487.

WELLS RT (1978) Thermoregulation and activity rhythms in the hairy-nosed wombat, Lasiorhinus latifrons
(Owen), (Vombatidae). Australian Journal of Zoology 26: 639-651.

WITHERS PC (1992) Metabolism, water balance and temperature regulation in the golden bandicoot (Isoodon auratus). Australian Journal of Ecology 40: 523-531.

WITHERS PC, KC RICHARDSON \& RD WOOLLER (1990) Metabolic physiology of euthermic and torpid honey possums, Tarsipes rostratus. Australian Journal of Zoology 37: 685-693.

WITHERS PC, GG THOMPSON \& RS SEYMOUR (2000) Metabolic physiology of the north-western mole, Notoryctes caurinus (Marsupialia: Notoryctidae). Australian Journal of Zoology 48: 241-258. 